OAK RIDGE NATIONAL LABORATORY
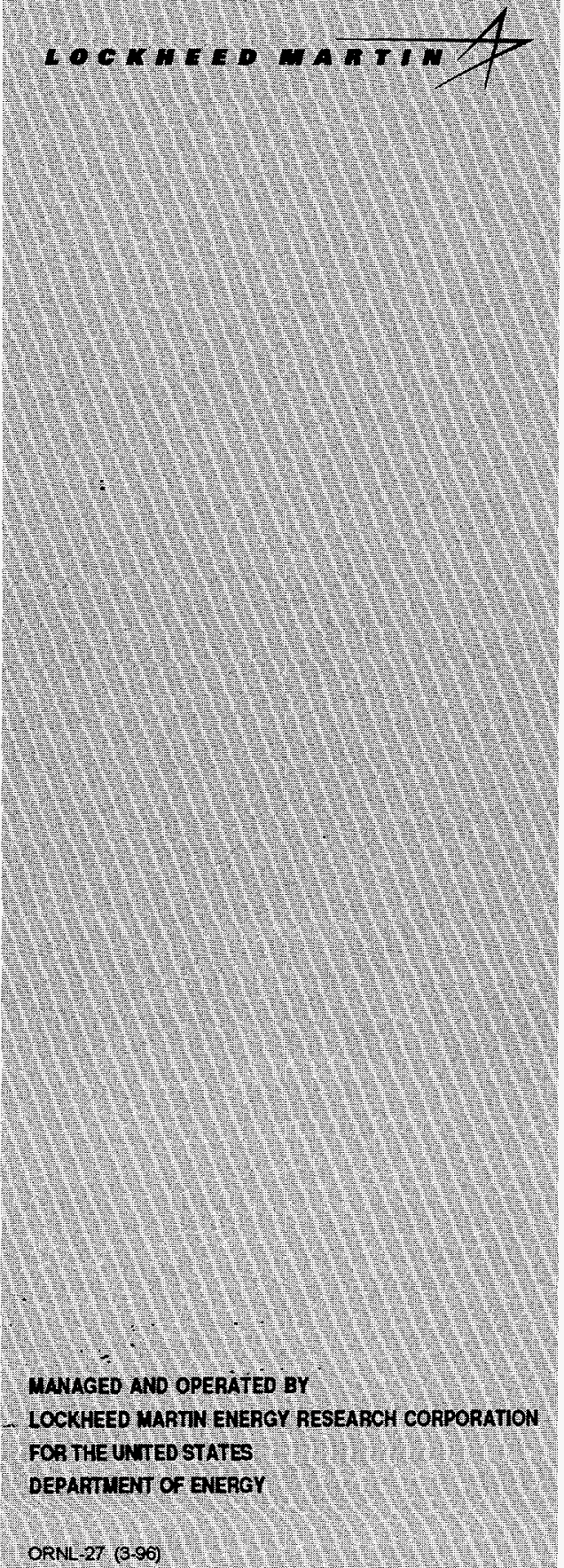

FECEYUED JUN 211996 OSTI

\title{
Quarterly Progress Report for the Chemical Development Section of the Chemical Technology Division: October-December 1995
}

\author{
R. T. Jubin
}


This report has been reproduced directly from the best available copy.

Available to DOE and DOE contractors from the Office of Scientific and Technical Information, P.O. Box 62, Oak Ridge. TN 37831; prices available from (615) 576-8401, FTS 626-8401.

Available to the public from the National Technical Information Service, U.S. Department of Commerce, 5285 Port Royal Rd., Springtield, VA 22161.

This report was prepared as an account of work sponsored by an agency of the United States Government. Neither the United States Government nor any agency thereof, nor any of their employees, makes any warranty, express or implied, or assumes any legal liability or responsibility for the accuracy, completeness, or usefulness of any information, apparatus, product, or process disclosed, or represents that its use would not infringe privately owned rights. Reference herein to any specific commercial product, process, or service by trade name, trademark, manufacturer, or otherwise, does not necessarily constitute or imply its endorsement, recommendation, or favoring by the United States Government or any agency thereot. The views and opinions of authors expressed herein do not necessarily state or reflect those of the United States Government or any agency thereof. 


\author{
Chemical Technology Division \\ QUARTERLY PROGRESS REPORT FOR THE CHEMICAL DEVELOPMENT \\ SECTION OF THE CHEMICAL TECHNOLOGY DIVISION: \\ OCTOBER-DECEMBER 1995
}

R. T. Jubin

Date Published-March 1996

\author{
Prepared by the \\ OAK RIDGE NATIONAL LABORATORY \\ Oak Ridge, Tennessee 37831-6285 \\ managed by \\ LOCKHEED MARTIN ENERGY RESEARCH CORP. \\ for the \\ U.S. DEPARTMENT OF ENERGY \\ under contract DE-AC05-96OR22464
}


.

. 


\section{DISCLAMMER}

Portions of this document may be illegible in electronic image products. Images are produced from the best available original document. 


\section{CONTENTS}

EXECUTIVE SUMMARY $\ldots \ldots \ldots \ldots \ldots \ldots \ldots \ldots \ldots \ldots \ldots \ldots \ldots \ldots \ldots$

1. CHEMICAL PROCESSES FOR WASTE MANAGEMENT $\ldots \ldots \ldots \ldots \ldots \ldots \ldots$.

1.1 COMPREHENSIVE SUPERNATE TREATMENT $\ldots \ldots \ldots \ldots \ldots \ldots \ldots \ldots$

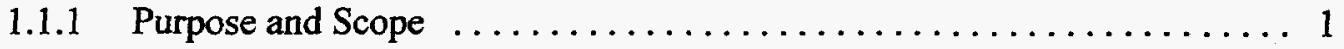

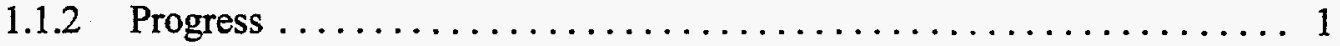

1.2 PARTITIONING OF SLUDGE COMPONENTS BY CAUSTIC LEACHING .... 4

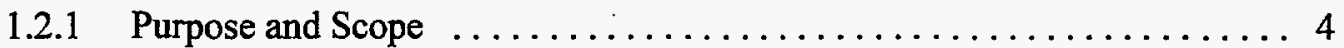

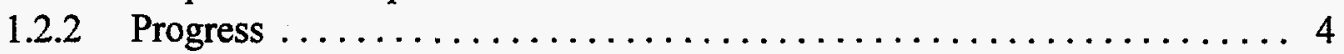

1.3 STUDIES ON TREATMENT OF DISSOLVED MVST SLUDGE USING

TRUEX PROCESS $\ldots \ldots \ldots \ldots \ldots \ldots \ldots \ldots \ldots \ldots \ldots \ldots \ldots \ldots \ldots \ldots \ldots \ldots \ldots \ldots$

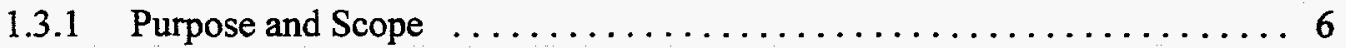

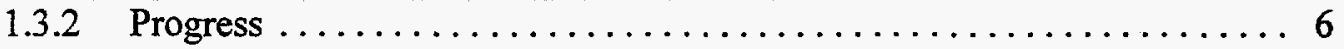

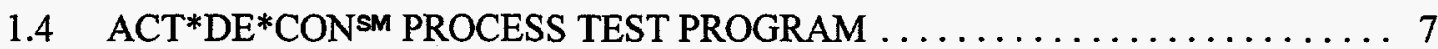

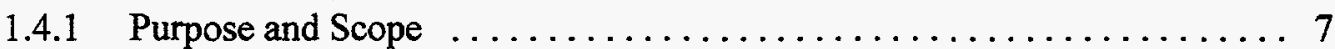

1.4 .2 Progress $\ldots \ldots \ldots \ldots \ldots \ldots \ldots \ldots \ldots \ldots \ldots \ldots \ldots \ldots \ldots$

1.5 HOT DEMONSTRATION OF PROPOSED COMMERCIAL NUCLIDE

REMOVAL TECHNOLOGY $\ldots \ldots \ldots \ldots \ldots \ldots \ldots \ldots \ldots \ldots \ldots \ldots \ldots \ldots \ldots$

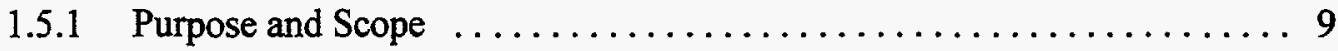

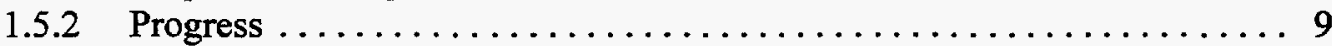

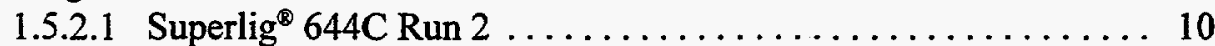

1.5 .2 .2 CST Run $1 \ldots \ldots \ldots \ldots \ldots \ldots \ldots \ldots \ldots \ldots \ldots \ldots \ldots \ldots$

1.5.2.3 CST Run $2 \ldots \ldots \ldots \ldots \ldots \ldots \ldots \ldots \ldots \ldots \ldots \ldots \ldots \ldots$

1.5.2.4 3M Web Material with Embedded Superlig ${ }^{\otimes} 644 \ldots \ldots \ldots \ldots 11$

1.5.2.5 Eichrome KCoFeC Granular Sorbent . . . . . . . . . . . . 12

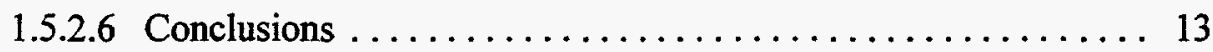

1.6 SLUDGE WASHING AND DISSOLUTION OF ORNL MVST WASTE:

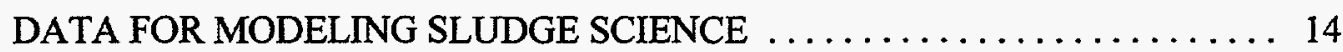

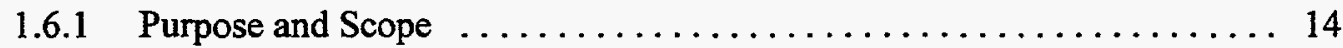

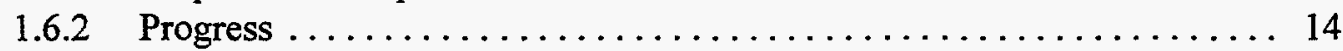

2. REACTOR FUEL CHEMISTRY-TECHNICAL ASSISTANCE IN REVIEW

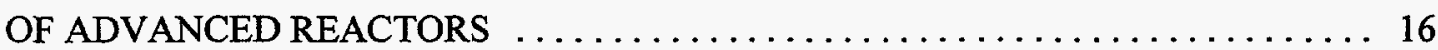

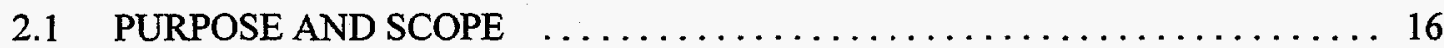

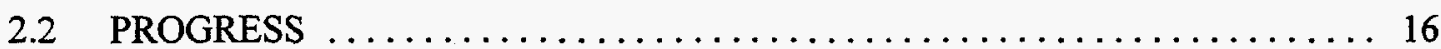

3. THERMODYNAMICS-THERMODYNAMICS AND KINETICS OF ENERGY-

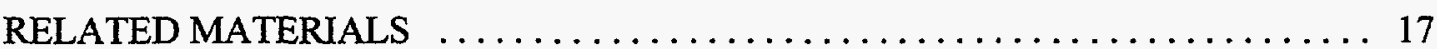

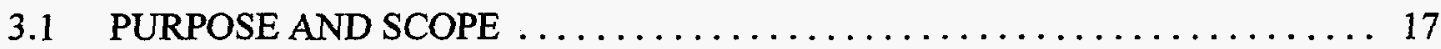

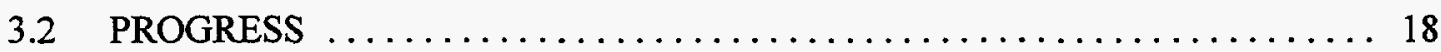


4. PROCESSES FOR WASTE MANAGEMENT-ION-EXCHANGE PROCESS

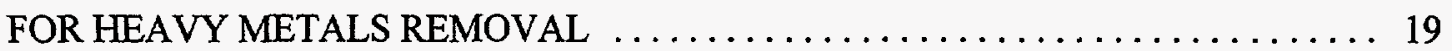

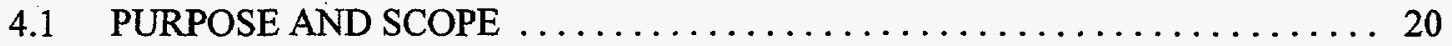

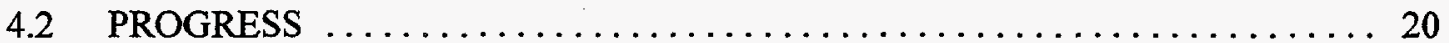

5. U.S. ARMY FIELD ARTILLERY LIQUID PROPELLANT STABILITY

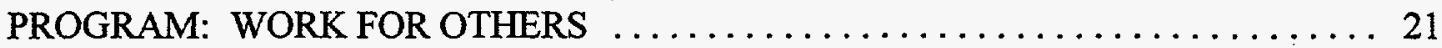

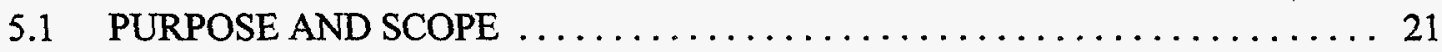

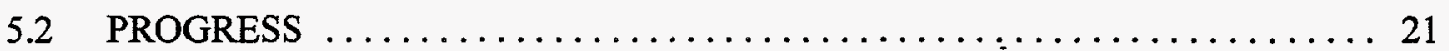




\section{EXECUTIVE SUMMARY}

This quarterly report is intended to provide a timely summary of the major activities being conducted in the Chemical Development Section of the Chemical Technology Division at the Oak Ridge National Laboratory (ORNL) during the period September-December 1995. The report summarizes ten major tasks conducted within five major areas of research and development within the section.

The first major research area-Chemical Processes for Waste Management-includes the following tasks: Comprehensive Supernate Treatment, Partitioning of Sludge Compounds by Caustic Leaching, Studies on Treatment of Dissolved MVST Sludge Using TRUEX Process, ACT*DE*CON ${ }^{\mathrm{sM}}$ Test Program, Hot Demonstration of Proposed Commercial Nuclide Removal Technology, and Sludge Washing and Dissolution of ORNL Waste: Data for Modeling Sludge Science.

The Comprehensive Supernate task is currently evaluating several sorbents in batch tests for removing strontium, technetium, and cesium from ORNL Melton Valley Storage Tank (MVST) supernatant solutions. Nine sorbents have been evaluated for removing strontium from MVST W-29 supernatant, and seven have been tested for technetium removal. All planned batch testing of cesium sorbents has been completed; however, additional cesium tests may be made as new sorbents become available. At the request of Hanford personnel, some batch tests were made to evaluate the effect on cesium distribution of selected sorbents which had been treated with an organic such as tributyl phosphate.

As part of the Partitioning of Sludge Components task, caustic dissolution tests on surrogate Hanford sludges have been completed, with significant quantities of aluminum, chromium, zinc, uranium, and phosphate being leached from the surrogate sludges. Tests on ORNL MVST sludge are continuing. Hot-cell tests to measure the dissolution behavior of MVST W-25 sludge in $3 \mathrm{MNaOH}$ at ambient temperature and at 75 and $95^{\circ} \mathrm{C}$ were completed, indicating that the dissolution of radioactive cesium increased significantly at the highest temperature. Preparations have been made for hot-cell tests on several samples of sludge obtained from Hanford waste tanks. An apparatus designed to test three samples simultaneously at temperatures up to $95^{\circ} \mathrm{C}$ in a hot cell has been fabricated and will be used to test the caustic leaching behavior of the Hanford sludge samples.

Work on the third task-Studies on Treatment of Dissolved MVST Sludge Using TRUEX Process-included analyses of samples collected during the two transuranium extraction (TRUEX) test campaigns. Results have been received from the ORNL Analytical Chemistry Division, and the data are currently being examined. The generic TRUEX model has been used to calculate aqueous- and 
organic-phase concentrations for the four-stage batch cross-flow experiment performed in the first campaign. Efforts to compare the calculated and measured concentrations are continuing. Analysis of the data are about one-third completed.

A test to evaluate the proprietary $\mathrm{ACT}^{*} \mathrm{DE}^{*} \mathrm{CON}^{\mathrm{SM}}$ process for selectively removing actinides from Gunite tank sludge was completed as part of the $A C T^{*} D E^{*} C O N^{S M}$ Test Program task. Analyses of the samples collected during the test were also completed.

The fifth task-Hot Demonstration of Proposed Commercial Nuclide Removal Technology-covers work in the continuous removal and concentration of radioactive components of supernatant at the various U.S. Department of Energy sites. The primary objective is to test candidate absorbers and ion exchangers under continuous-flow conditions using actual supernatant from the MVSTs. An experimental system contained in a hot-cell facility is used to test the materials in columns or modules using the same batch of supernatant so that results can be directly compared. During the current reporting period, SuperLig ${ }^{\circledR} 644 \mathrm{C}$ resin and a WEB material from $3 \mathrm{M}$ with embedded SuperLig ${ }^{\circledR} 644$ were tested over one loading/elution/regeneration cycle. Crystalline silicotitanates from UOP were tested at two loading flow rates, and $\mathrm{KCoFeC}$ from Eichrome was tested at one flow rate.

As part of the final task within the Chemical Processes for Waste Management area-Sludge Washing and Dissolution of ORNL Waste-seven samples of Hanford underground storage tank sludge were obtained. Three caustic treatment tests were conducted on sludge from Hanford Underground Storage Tank T-104 to assess the distribution of species between aqueous solutions and solids and to evaluate gel formation. Analytical results from these tests showed that comparable amounts of aluminum were removed at each of three temperatures but that a greater removal of phosphate occurred in the room temperature test than in the tests at elevated temperature. Chromium removal was enhanced by leaching at elevated temperatures. Gels were observed in leachates from the tests at elevated temperatures $1 \mathrm{~d}$ after the treatments concluded, and a gel formed in the first wash after leaching in the room temperature test as well.

Within the area of Reactor Fuel Chemistry, the Technical Assistance in Review of Advanced Reactors task evaluated the distribution of iodine in the containment vessel during an AP600 design basis accident (a medium loss-of-coolant accident) by using a group of models known collectively as the TRENDS code. Results of previous studies have shown that $\mathrm{pH}$ is the major factor in determining the amount of $\mathrm{I}_{2}$ and organic iodides in containment water pools. When the $\mathrm{pH}$ is $<7$ (acidic), these volatile iodine species can form. The AP600 3BE accident sequence calculations showed that $\mathrm{pH}>7$ 
was maintained for at least $30 \mathrm{~d}$. Because the $\mathrm{pH}$ was maintained above 7 , most of the iodine was in the form of iodide in water pools, not in a volatile form such as $\mathrm{I}_{2}$ or an organic iodide.

The Thermodynamics and Kinetics of Energy-Related Materials task within the Thermodynamics area has been conducting several different experiments to obtain information on the effects of oxygen nonstoichiometry, temperature (T), and oxygen partial pressure (p) on the superconducting transition temperature $\left(\mathrm{T}_{c}\right)$ and phase behavior of $\mathrm{R}-\mathrm{Ba}-\mathrm{Ca}-\mathrm{Cu}-\mathrm{O}$ compounds. Experimental work continues on the $T$-p-z-y interdependence in the $\mathrm{Pd}_{1+z} \mathrm{Ba}_{2-z} \mathrm{Cu}_{3} \mathrm{O}_{\mathrm{y}}$ solid solution. The effect of specimen density, temperature, and grain size on the attainment of equilibrium $7-x$ values is also being investigated for the $\mathrm{YBa}_{2} \mathrm{Cu}_{3} \mathrm{O}_{7-x}(\mathrm{Y} 123)$ system. To date, thermogravimetric analysis experiments have been done with the world's largest Y123 single crystal, a 95-g specimen, and a similar 15-g crystal, both of which are theoretically dense. These experiments have defined the initial 7- $x$ value. Two journal articles have been published.

Ion-Exchange Process for Heavy Metals Removal-a task currently ongoing within the Processes for Waste Management area-demonstrates a pilot-scale ion-exchange system to remove heavy metals from multiple sites (originally from an acid mine site only) using the most effective commercially available sorbent based on laboratory screening experiments. This system will operate alongside three novel treatment systems and act as baseline technology. In the past quarter, a column test using Amberlite IRC-50 ${ }^{\mathrm{TM}}$ was performed based on the composition of the original acid mine site with 2 ppm of zinc added. This column ran 5000 bed volumes before breakthrough of zinc. Unfortunately, this site is no longer going to be used in the program, and no information on the new sites has yet been received. The conceptual design of the pilot-scale system has been completed, and purchase of the necessary equipment is under way.

Finally, the Chemical Development Section has been involved in work-for-others activities involving the U.S. Army Field Artillery Liquid Propellant Stability Program. As part of this effort, pressure-rise scoping tests continued at both 50 and $65^{\circ} \mathrm{C}$. Some tests in which a special inorganic stabilizer was used to stabilize the energetic liquid propellant (LP) have now exceeded $120 \mathrm{~d}$ without any increase in pressure associated with the decomposition of the LP into various gaseous degradation by-products. The additive appears to be the answer to the Army's long search for an acceptable stabilizer. In the coming weeks, the Army will test the additive in the Army Research Laboratory at the Aberdeen Proving Grounds to investigate its stability at higher controlled temperatures as well as to investigate its effect upon the burn rate of the LP in calorimeters. 


\title{
1. CHEMICAL PROCESSES FOR WASTE MANAGEMENT
}

\author{
B. Z. Egan
}

\subsection{COMPREHENSTVE SUPERNATE TREATMENT (J. L. Collins, K. K. Anderson, and} B. Z. Egan)

Contact: B. Zane Egan

Telephone: (423) 574-6868

Internet: eganbz@ornl.gov

Summary: Several sorbents are being evaluated in batch tests for removing strontium, technetium, and cesium from Oak Ridge National Laboratory (ORNL) Melton Valley Storage Tank (MVST) supernatant solutions. Nine sorbents have been evaluated for removing strontium from MVST W-29 supernatant, and seven have been tested for technetium removal. All planned batch testing of cesium sorbents has been completed; however, additional cesium tests may be made as new sorbents become available. At the request of Hanford personnel, some batch tests were made to evaluate the effect on the cesium distribution of selected sorbents which had been treated with an organic such as tributyl phosphate.

\subsubsection{Purpose and Scope}

This task involves testing sorbent materials for removing cesium, strontium, and technetium from the saline solutions in U.S. Department of Energy (DOE) storage tank supernatant at Oak Ridge and other sites. Batch tests are used to evaluate and select the most promising materials for supernatant treatment to reduce the amount of waste for final disposal. Small-column tests will be made on selected sorbents to verify the batch data and to obtain additional data for process design. Methods will be evaluated for recovering the radionuclides from the sorbents.

Supernatants used in the tests have been retrieved from MVST W-25, W-27, and W-29. These supernatants have many similarities to supernatants in tanks at other DOE sites. Efforts will be made to obtain samples of tank supernatants from Hanford for comparison. Many of the sorbents have been proposed for waste treatment, but most have not been tested on actual waste solutions.

\subsubsection{Progress}

Bench-scale batch equilibrium tests were conducted with supernatant from ORNL MVST to evaluate selected ion exchangers for removing strontium and technetium. A treated supernatant stock solution was prepared by mixing the supernatant with resorcinol/formaldehyde (R-F) resin and then with potassium cobalt hexacyanoferrate to remove most of the cesium and strontium activity. This stock solution was divided into two parts for use in the strontium and technetium batch tests. For the strontium tests, strontium was added to the solution as strontium nitrate, traced with ${ }^{85} \mathrm{Sr}$, to 
give a concentration of $1.5 \mathrm{mg} / \mathrm{L}$. For the technetium tests, ${ }^{99} \mathrm{Tc}$ was added as ammonium pertechnetate to give a technetium concentration of $4.0 \mathrm{mg} / \mathrm{L}$.

To remove strontium from the supernatant, nine different sorbents were tested at ambient temperature for different mixing times, using a range of supernatant-to-sorbent ratios from 100 to 2000. The sorbents tested were sodium titanate, crystalline silicotitanate, titanium monohydrogen phosphate, titanium monohydrogen phosphate-polyacrylonitrile, sodium titanate-polyacrylonitrile, Amberlite IRC-718, Duolite C467, Chelex 100, and R-F resin. Strontium distribution ratios greater than $20,000 \mathrm{~mL} / \mathrm{g}$ were obtained for sodium titanate and crystalline silicotitanate. Distribution ratios of the other sorbents ranged from 1000 to $10,000 \mathrm{~mL} / \mathrm{g}$.

Tests were conducted with seven different anion-exchange resins to remove pertechnetate from the supernatant solution. The resins tested were Eichrom Tc-Resin, Purolite A520E, Amberlite IRA-904, Reillex HPQ, Reillex HP, Amberlite IRA-400, and Reillex 402. The technetium distribution ratios ranged from 400 to $900 \mathrm{~mL} / \mathrm{g}$, with a maximum technetium removal of $88 \%$.

Additional batch tests were conducted with samples of granular crystalline silicotitanate (UOP IONSIV IE-911) and granular sodium titanate (Allied Signal) to measure the strontium removal from MVST W-27 supernatant. The supernatant that was used was effluent from a column run in which most of the cesium was removed using R-F resin. The supernatant effluent was further treated by mixing it for $2 \mathrm{~h}$ with granular potassium cobalt hexacyanoferrate to remove additional cesium. Then strontium nitrate, containing ${ }^{85} \mathrm{Sr}$ tracer, was added to provide a strontium concentration of $1.5 \mathrm{mg} / \mathrm{L}$. Duplicate samples were mixed for periods of $0.25,2,24$, and $144 \mathrm{~h}$ at ambient temperature. The strontium distribution ratios for the Allied Signal sodium titanate samples ranged from 380 to $1400 \mathrm{~mL} / \mathrm{g}$. These values are somewhat lower than values obtained with sodium titanate powder with W-29 supernatant. Values obtained for the IONSIV IE-911 material are not yet available because of a confidentiality agreement but will be reported later.

Samples of anion exchangers obtained from NUCON International, Inc., were tested for removing technetium from MVST W-29 supernatant. These spherical ion exchangers, NUSORB LP70-S, consist of a porous activated carbon substrate impregnated with amines, either Aliquat, TEDA, or piccoline. Duplicate batch tests were conducted by mixing the supernatant and ion exchangers for $24 \mathrm{~h}$. The technetium (pertechnetate) distribution ratios were $410 \mathrm{~mL} / \mathrm{g}(68 \%$ removal) for NUSORB LP70-S (Aliquat), $380 \mathrm{~mL} / \mathrm{g}$ (65\% removal) for NUSORB LP70-S (TEDA), and $450 \mathrm{~mL} / \mathrm{g}$ (68\% removal) for NUSORB LP70-S (piccoline). These values are near the lower end 
of the range of the anion exchangers that have been tested under similar conditions for technetium removal.

Preparations are under way for small-column tests of selected sorbents for strontium and technetium removal from supernatants. The necessary column chromatographic equipment is being assembled and tested.

A paper entitled "Removal of Sr and Tc from Supernatant from ORNL Underground Storage Tanks" was presented at the Ninth Symposium on Separation Science and Technology for Energy Applications, Gatlinburg, Tennessee, October 22-26, 1995. A poster, "Treatment of Technetium Wastes from DOE Underground Storage Tanks," was presented at the AIChE National Convention, Miami Beach, Florida, November 12-17, 1995.

Some of the underground storage tanks at Hanford contain a layer of organic liquid along with the supernatant. Ion-exchange processes have been proposed for treating the supernatant. These layers of liquid may contain organics such as tributyl phosphate and could be introduced directly to the ion-exchange columns. Hanford personnel requested that we make some tests to determine the possible effects of the organic liquids on ion exchangers.

Bench-scale batch equilibrium tests were conducted with supernatant from ORNL MVST to evaluate the effects of organics on cesium removal by selected ion exchangers. Samples of R-F resin, Superlig $644 \mathrm{C}$, and crystalline silicotitanate (CST) sorbents were tested. The sorbents were used as received. In one set of tests, samples of the sorbents were soaked in tributyl phosphate before mixing with the supernatant. Approximately $0.025 \mathrm{~g}$ of sorbent was soaked in $0.8 \mathrm{~mL}$ of tributyl phosphate for $24 \mathrm{~h}$ prior to adding $5.0 \mathrm{~mL}$ of supernatant. For comparison, in another set of tests, the sorbents were mixed with supernatant without being exposed to the tributyl phosphate. Cesium removal was measured after mixing times of 1 and $24 \mathrm{~h}$. Soaking the sorbents in tributyl phosphate decreased the cesium distribution ratios. In the $24-\mathrm{h}$ tests, the cesium distribution ratio for the R-F resin decreased from 525 to $75 \mathrm{~mL} / \mathrm{g}$, the Superlig $644 \mathrm{C}$ decreased from 480 to $330 \mathrm{~mL} / \mathrm{g}$, and the CST decreased from 1000 to $570 \mathrm{~mL} / \mathrm{g}$.

These preliminary batch tests indicate that the organic liquids could have a significant detrimental effect on the behavior of the ion exchangers. Additional tests are needed to determine the effects of the specific organic liquids in the tanks on the ion exchangers in continuous column operations. These tests could determine whether an organic/aqueous separation step is required or whether other provisions are needed to prevent the organic from affecting the column performance. 


\subsection{PARTITIONING OF SLUDGE COMPONENTS BY CAUSTIC LEACHING (B. Z. Egan, J. L. Collins, D. D. Ensor ${ }^{*}$, and C. W. Chase)}

Contact: B. Zane Egan

Telephone: (423) 574-6868

Internet: eganbz@ornl.gov

Summary: Caustic dissolution tests on surrogate Hanford sludges have been completed. Significant amounts of aluminum, chromium, zinc, uranium, and phosphate were leached from the surrogate sludges. Tests on ORNL MVST sludge are continuing. Hot-cell tests to measure the dissolution behavior of MVST W-25 sludge in $3 \mathrm{MNaOH}$ at ambient temperature and at 75 and $95^{\circ} \mathrm{C}$ were completed. The dissolution of radioactive cesium increased significantly at the highest temperature. Preparations have been made for hot-cell tests on several samples of sludge obtained from Hanford waste tanks. An apparatus designed to test three samples simultaneously at temperatures up to $95^{\circ} \mathrm{C}$ in the hot cell has been fabricated. This apparatus will be used to test the caustic leaching behavior of the Hanford sludge samples.

\subsubsection{Purpose and Scope}

Many underground storage tanks contain high concentrations of nonradioactive materials such as aluminum, chromium, and phosphates that can significantly increase the volume of the final high-level waste (HLW) waste form for disposal. There is increasing emphasis on removing these materials through "enhanced sludge washing," such as taking advantage of the solubility of these materials under very caustic conditions to partition the radioactive and nonradioactive components. The behavior of some of the components, such as chromium and phosphate, is also important to vitrification processes. A purpose of this project is to measure the caustic dissolution behavior of sludge components from ORNL MVST sludge, surrogate Hanford sludges, and selected Hanford sludge samples. If the nonradioactive components could be preferentially solubilized, then the volume of the remaining radioactive waste to be treated and/or stored would be significantly reduced.

\subsubsection{Progress}

Studies using surrogate Hanford sludges have been essentially completed. Three surrogate sludges were prepared and used for caustic dissolution tests. All three sludges were also "aged" by heating the wet sludge to $97^{\circ} \mathrm{C}$ for $5 \mathrm{~d}$. Various experiments were performed to characterize the distribution of the sludge components as a function of sodium hydroxide concentration and temperature. Significant amounts of aluminum, chromium, zinc, uranium, and phosphate were removed from the surrogate sludges by caustic leaching. Only small amounts of iron, calcium, and

\footnotetext{
"Tennessee Technological University, Cookeville, Tennessee.
} 
bismuth were leached, even with $6 \mathrm{MNaOH}$. The removal of thorium was insignificant. The aging process tended to decrease the removal of aluminum and zinc while increasing the chromium removal. The addition of aluminum to the sludge in the form of gibbsite decreased the amount of aluminum leached. Phosphate removal from all of the surrogate sludges was high. Results from these surrogate sludges compared in many ways with the results obtained at Pacific Northwest Laboratory with several actual Hanford sludge samples (B. M. Rapko, G. J. Lumetta, and M. J. Wagner, Washing and Caustic Leaching of Hanford Tank Sludges: Results of FY 1995 Studies, PNL-10712/UC-721, August 1995). A poster summarizing these studies, "Alkali Washing of Simulated Waste Sludge," was presented at the Ninth Symposium on Separation Science and Technology for Energy Applications, Gatlinburg, Tennessee, October 22-26, 1995.

Samples of sludge from Hanford tanks C-107, BX-105, C-108, TY-104, B-202, S-104, and $\mathrm{T}-107$ were received for use in future studies. Characterization data on these sludges are being compiled. An apparatus has been designed and fabricated for caustic leaching tests on available samples of Hanford sludge. The apparatus is designed to test three samples simultaneously at temperatures up to $95^{\circ} \mathrm{C}$ in the hot cell. Parts of the system are being tested with simulated sludge to verify the procedures that will be used in the hot-cell tests.

Caustic leaching tests on ORNL MVST W-25 sludge are continuing. The effect of temperature on the dissolution behavior in $3 \mathrm{MNaOH}$ is being measured. Sludge samples were leached at ambient temperature and at 75 and $95^{\circ} \mathrm{C}$.

A 30-g sample of centrifuged wet-sludge solids was mixed with $3.2 \mathrm{MNaOH}$ for $8 \mathrm{~h}$ at $95^{\circ} \mathrm{C}$. The residue was then washed three times with $0.16 \mathrm{MNaOH}$. The test resulted in the removal of about $16 \%$ of the sludge solids. About $22 \%$ of the cesium and $0.4 \%$ of the cobalt were removed. In a previous test using a shorter (4-h) mixing time, $15 \%$ of the cesium and $0.5 \%$ of the cobalt were removed.

In a similar test, a 31-g sample of centrifuged wet-sludge solids was mixed with $98 \mathrm{~mL}$ of $3.2 \mathrm{MNaOH}$ for $8 \mathrm{~h}$ at $75^{\circ} \mathrm{C}$. The residue was then washed three times with $0.16 \mathrm{MNaOH}$. The test resulted in the removal of about $7.1 \%$ of the cesium. This was similar to the amount of cesium removed at ambient temperature. These tests indicate that restructuring or reaction of the solids allows the release of more cesium at the higher temperature. Consequently, temperature could be used as a variable in partitioning of the cesium between the sludge and leachate. 
Additional analyses for aluminum, chromium, zinc, and other nonradioactive components are under way. These results will be used to evaluate the separation of radioactive and nonradioactive components of the sludge by caustic leaching.

\subsection{STUDIES ON TREATMENT OF DISSOLVED MVST SLUDGE USING TRUEX PROCESS (B. B. Spencer ${ }^{\star}$ and C. W. Chase)}

Contact: Barry B. Spencer

Telephone: (423) 574-7143

Internet: spencerbb@ornl.gov

Summary: Results of the analyses of samples collected during the two transuranium extraction (TRUEX) test campaigns have been received from the ORNL Analytical Chemistry Division. These data are currently being examined. The generic TRUEX model (GTM) has been used to calculate aqueous- and organic-phase concentrations for the four-stage batch cross-flow experiment performed in the first campaign. Efforts to compare the calculated and measured concentrations are continuing. Analysis of the data are about one-third completed.

\subsubsection{Purpose and Scope}

The focus of this experimental program was to evaluate the TRUEX solvent extraction process for partitioning actinides from actual $\mathrm{HLW}$ sludge dissolved in nitric acid. A large sludge sample was previously removed from MVST W-25, has been well characterized, and was available for the test program. The experimental phase of the evaluation program included dissolving portions of this sludge in nitric acid, followed by batch liquid-liquid equilibrium tests of both the extraction and stripping operations. Chemical analyses of both phases will be used to evaluate the process. Evaluation is based on two metrics, the fraction of transuranic (TRU) elements removed from the dissolved sludge and comparison of the results with predictions made with the GTM.

\subsubsection{Progress}

Two TRUEX test campaigns were completed last fiscal year. In the first campaign, washed sludge samples were dissolved using $5.5 \mathrm{M}$ nitric acid, resulting in dissolved sludge solution having a cation concentration (not including $\mathrm{H}^{+}$) of $\sim 1.8 \mathrm{M}$ and a nitric acid concentration of $\sim 2.9 \mathrm{M}$. A four-stage batch cross-flow TRUEX process was performed, in which the dissolved sludge was treated with two sequential extractions and the organic from the first extraction was stripped with

\footnotetext{
*Robotics and Process Systems Division, ORNL.
} 
dilute nitric acid in two sequential batches. A portion of the filtered dissolved sludge solution was set aside for several days during which it gelled almost completely.

Dissolution of the sludge for a second TRUEX experiment was carried out under less aggressive conditions and was designed to make a less concentrated solution to reduce the formation of gels. The final dissolution resulted in a solution containing cation concentrations (not including $\mathrm{H}^{+}$) of $\sim 0.6 \mathrm{M}$ and a nitric acid concentration of $\sim 2.0 \mathrm{M}$. Before performing the TRUEX tests, the dissolved sludge solution was filtered with $0.45-\mu \mathrm{m}$-porosity syringe filters with little difficulty. The TRUEX test consisted of a four-stage batch cross-flow process, in which the dissolved sludge was treated with a single extraction and the equilibrated organic was stripped with dilute nitric acid in three sequential batches. Gelation of the dissolved sludge was very much slower in the second test than in the first experiment.

Results of the analyses of samples collected during the two TRUEX test campaigns have been received from the ORNL Analytical Chemistry Division. These data are currently being examined. The GTM has been used to calculate aqueous- and organic-phase concentrations for the four-stage experiment performed in the first campaign. Efforts to compare the calculated and measured concentrations are continuing. Analysis of the data are about one-third completed.

\section{$1.4 \quad$ ACT $^{*}$ DE $^{*}$ CON $^{\text {SM }}$ PROCESS TEST PROGRAM (B. B. Spencer and C. W. Chase) \\ Contact: Barry B. Spencer \\ Telephone: (423) 574-7143 \\ Internet: spencerbb@ornl.gov}

Summary: A test to evaluate the proprietary $A C T^{*} D E^{*} C O N^{S M}$ process for selectively removing actinides from Gunite tank sludge was completed. Analyses of the samples collected during the test were also completed.

\subsubsection{Purpose and Scope}

The $\mathrm{ACT}^{*} \mathrm{DE}^{*} \mathrm{CON}{ }^{\mathrm{SM}}$ process, a proprietary process of Selective Environmental Technologies, Inc. (Selentec), is designed to remove actinides from soils or soil-like media. The process is proposed as an alternative for removal of actinides from tank-stored HLW sludges. The $\mathrm{ACT}^{*} \mathrm{DE}^{*} \mathrm{CON}^{\mathrm{SM}}$ solvent is an aqueous carbonate solution containing a chelating agent and an oxidant. This combination of chemicals is rather benign and is intended to leach specific metal species from a soil matrix without destroying the bulk of the soil. The objective of the test program 
is to evaluate the $A C T * \mathrm{DE}^{*} \mathrm{CON}^{\mathrm{SM}}$ process for pretreating Gunite and Associated Tanks sludge as part of the sludge-processing flow-sheet development effort.

\subsubsection{Progress}

Sludge samples from Gunite tanks W-3, W-6, and W-10 were available for the test. However, funding and schedule constraints permitted testing on sludges from only one of the tanks. The tests were carried out in consultation with representatives from Selentec, who participated in the selection of the sample to be tested, provided the formulation of the $\mathrm{ACT}^{*} \mathrm{DE} * \mathrm{CON}^{\mathrm{SM}}$ solvent, and reviewed the test procedure.

A test to evaluate the $A C T^{*} \mathrm{DE}^{*} \mathrm{CON}^{\mathrm{SM}}$ process for selectively removing actinides from Gunite tank sludge was completed. Mixed waste sludge from Gunite tank W-6 was subjected to the $\mathrm{ACT}^{*} \mathrm{DE}^{*} \mathrm{CON}^{\mathrm{SM}}$ selective leaching process. Nearly all the TRU content of this sludge was plutonium. The sludge sample was first washed with a mild caustic solution $(\sim 0.01 M)$ to remove excess sodium and nitrate associated with the interstitial liquid supernatant. The washed wet solids were treated with the $\mathrm{ACT}^{*} \mathrm{DE}^{*} \mathrm{CON}^{\mathrm{SM}}$ solvent using a ratio of $\sim 20 \mathrm{~mL}$ of solvent per gram of wet solids. The sludge and solvent were separated by centrifugation and the $\mathrm{ACT}^{*} \mathrm{DE}^{*} \mathrm{CON}^{\mathrm{SM}}$ treatment repeated twice. On a wet basis the overall solvent-to-sludge ratio was $\sim 60 \mathrm{~mL} / \mathrm{g}$, but on a dry basis the ratio was $\sim 178 \mathrm{~mL} / \mathrm{g}$.

Samples of the spent solvents (leachates) and residual sludge solids were analyzed. The results indicated that $\sim 71 \%$ of the solids in the sludge were dissolved while $\sim 80 \%$ of the TRU components dissolved. A low separation of the TRU components from the sludge is indicated. Almost all the uranium and calcium were removed from the sludge. On a dry-solids basis, the total TRU content of the washed sludge was $376 \mathrm{nCi} / \mathrm{g}$ and that of the treated sludge was $250 \mathrm{nCi} / \mathrm{g}$. The process did not render the sludge a non-TRU waste $(<100 \mathrm{nCi} / \mathrm{g})$.

For sludges in which most of the TRU content is plutonium, the $A C T * D E * C O N^{S M}$ process, in its present form, is not effective in rendering the sludge a non-TRU waste. It is recommended that other processes utilizing different chelating and oxidizing agents be tested. Additionally, the $\mathrm{ACT}^{*} \mathrm{DE}^{*} \mathrm{CON}^{\mathrm{SM}}$ process should be tested on TRU mixed waste in which the bulk of the TRU components are elements other than plutonium. 

TECHNOLOGY (D. D. Lee and J. R. Travis)

Contact: D. D. Lee

Telephone: (423) 576-2689

Internet: Leedd@ornl.gov

Summary: This task covers work in the continuous removal and concentration of radioactive components of supernatant at the various DOE sites. The primary objective is to test candidate absorbers and ion exchangers under continuous-flow conditions using actual supernatant from the MVSTs. An experimental system contained in a hot-cell facility is used to test the materials in columns or modules using the same batch of supernatant so that results can be directly compared. During the current reporting period, SuperLig ${ }^{\otimes} 644 \mathrm{C}$ resin and a WEB material from $3 \mathrm{M}$ with embedded SuperLig ${ }^{\circledR} 644$ were tested over one loading/elution/ regeneration cycle. CSTs from UOP were tested at two loading flow rates, and $\mathrm{KCoFeC}$ from Eichrome was tested at one flow rate.

\subsubsection{Purpose and Scope}

This task covers the operation of an experimental test unit which is located in a Building 4501 hot cell. This equipment is designed to test radionuclide removal technologies under continuous operation on actual ORNL MVST supernatant, Savannah River HLW supernatant, and Hanford supernatant. The latter two may be simulated by adding the appropriate chemicals and/or nuclides to the MVST supernatant. The technologies tested are housed in modules or placed in columns which can be attached to the experimental system inside the hot cell and continuously fed the test supernatant until the nuclide of interest exhausts the capacity of the module. Initial candidate sorbents for cesium removal are the R-F resin, CSTs, Superlig 644 resin, and granular potassium cobalt hexacyanoferrate. Sodium and potassium are competitors for cesium removal. The results of these tests will be compared with batch results and small-column tests results obtained in the Comprehensive Supernatant Treatment task (B. Z. Egan). The results will be used to supply the Cesium Removal Demonstration Project (T. E. Kent) with the information to determine the design parameters for that project. The rate of removal, resin required, and regeneration requirements are important design parameters, and the loading capacity of each sorbent will help to determine the size of the column required and help define the final volume of solid waste to be disposed of.

\subsubsection{Progress}

Several ion-exchange material tests were completed in Hot Cell $\mathrm{C}$ during the first quarter of FY 1996. The feed supernatant for the tests was obtained from MVST W-27 in April 1995. Tank W-27 contains supernatant at $\mathrm{pH} 7.2$ and has the lowest potassium and ${ }^{137} \mathrm{Cs}$ levels of the available 
tanks. This supernatant was adjusted back to the $\mathrm{pH}$ standard in other tanks, about $\mathrm{pH} 12.5$ to 13.0 . Analysis of the present sample after $\mathrm{pH}$ adjustment to 12.85 and filtration showed about $9.3 \times 10^{-6}$ $\mathrm{Ci} / \mathrm{mL}$ of ${ }^{137} \mathrm{Cs}$.

\subsubsection{SuperLig ${ }^{\circledR} 644$ C Run 2}

The SuperLig ${ }^{\circledR}$ was prepared by adding dry resin to distilled water and allowing it to wet overnight. It was then prepared for operation by adding $2 \mathrm{~N} \mathrm{NaOH}$, pumping in upflow mode, and stirring to remove air bubbles. The final volume was $11.2 \mathrm{~mL}$.

After W-27 supernatant feed was started to the column, clumps of bed material formed at the top of the bed. The initial feed rate through the column was 6.4 column volumes $(\mathrm{CV}) / \mathrm{h}$. This was reduced to $6.0 \mathrm{CV} / \mathrm{h}$ soon after the start. As the initial 1 to $2 \mathrm{CV}$ of feed left the column, a great deal of color passed from the bed with it. The run continued until breakthrough had reached over $50 \%$, and the flow rate through the column was then changed to $3 \mathrm{CV} / \mathrm{h}$ to observe any variations in the loading curve slope and for comparison with the first SuperLig ${ }^{\otimes} 644 \mathrm{C}$ run, which had to be ended before a reliable slope was obtained. This reduced rate was continued for $4 \mathrm{~h}$. An initial decrease in the breakthrough with an increase in the slope of the loading curve was observed. The feed was then cut off, the column rinsed with water, and preparations made for the elution.

The elution of the loaded cesium was started by pumping the $0.5 \mathrm{NHNO}_{3}$ through the column at a $3-\mathrm{CV} / \mathrm{h}$ flow rate. After the acid started through the column, colored liquid could be seen leaving the column. The elution curve was steep, and all of the loaded cesium was recovered in about $4 \mathrm{CV}$, with the peak concentration of cesium at about 25 times the W-27 concentration.

\subsubsection{CST Run 1}

CSTs from UOP, IONSIV IE-911 \#07398-38B, were run in the Cell C equipment in a 1.5$\mathrm{cm}$-ID column using a volume of $10 \mathrm{~cm}^{3}$, with a bed height of $6 \mathrm{~cm}$. The dry tapped density of the material was $1.155 \mathrm{~g} / \mathrm{cm}^{3}$. This IONSIV is a developmental sample supplied by UOP, and improved materials are currently under development by UOP. The column was flushed with $0.1 \mathrm{MNaOH}$ in upflow mode to wet the packing and remove bubbles. The bed was 6.0 to $6.1 \mathrm{~cm}$ after tapping and settling. The column was operated at $3 \mathrm{CV} / \mathrm{h}$ in downflow mode for a total of over $435 \mathrm{CV}$, with $50 \%$ breakthrough occurring at about $370 \mathrm{CV}$. No problems that could be attributed to the ion exchanger occurred during the continuous run of more than $144 \mathrm{~h}$. 
The level of ${ }^{137} \mathrm{Cs}$ in the column effluent was low (below $1 \%$ breakthrough) through more than $100 \mathrm{CV}$. Further data were obtained based on the analyses of the samples obtained during the run. These samples were obtained from the fractions collected during the loading of the ion exchanger by a fraction collector, which channels all output from the column into successive 250-mL sample bottles. The fraction collector was set to collect for about $4 \mathrm{~h}$ per bottle $(\sim 120 \mathrm{~mL})$ or $12 \mathrm{CV}$ per sample bottle. These results were then compared with the data obtained using the on-line detector inside the cell. The results from these two methods agreed very well.

\subsubsection{CST Run 2}

The same experimental setup was used to perform the second experiment using the CSTs. The test sorbent was taken from the same sample bottle of UOP Batch 38B CST used in the CST Run 1. The column was prepared using $11.727 \mathrm{~g}$ (6-cm tapped bed height in the column) of sorbent with a final volume before the start of the run of $10.23 \mathrm{~mL}$. The supernatant used for the majority of the loading was prepared in September 1995 to a $\mathrm{pH}$ of 12.85. During the run, additional supernatant was adjusted to approximately the same $\mathrm{pH}$ and used for the last $100 \mathrm{CV}$ of feed to the column. All the supernatant was obtained in April 1995 from MVST W-27.

Once the column was installed in the system, feed supernatant was pumped to the column and the flow started at about $6 \mathrm{CV} / \mathrm{h}$ through the column. Flow continued until the effluent showed a ${ }^{137} \mathrm{Cs}$ level $>50 \%$ of the level in the feed. The results of the loading showed a more gradual increase in the effluent cesium concentration, which is expected for kinetic control of the loading of cesium onto the CST. The breakthrough of cesium at the $50 \% \mathrm{C} / \mathrm{C}_{0}$ was very close to that obtained at $3 \mathrm{CV} / \mathrm{h}$. The change in feed after $200+\mathrm{CV}$ appeared to have no effect on the slope of the curve or other operating parameters.

\subsubsection{3M Web Material with Embedded SuperLig ${ }^{\circledR} 644$}

The 3M WEB filter was installed in an apparatus to interface with the cell system and was placed in the cell. The filter was prepared by running water and then $2 \mathrm{MNaOH}$ through the filter in an upflow mode. Fifteen milliliters of $\mathrm{NaOH}$ was passed through ( $\sim 12$ filter volumes). A significant amount of color from filter was observed in the effluent that was sent to the drain. During the caustic treatment, a significant pressure increase on the pump was noticed. Some of the $\mathrm{NaOH}$ was left in filter at the end of the caustic treatment. 
Supernatant feed was then pumped to the feed column, and flow was started to the filter. After the feed was started and the supernatant reached the filter, brown color was seen leaving the web. The feed rate was stabilized at the about $1 \mathrm{~mL} / \mathrm{min}$; the run continued at that rate for the remainder of the loading cycle. The average flow rate for the loading was $1.07 \mathrm{~mL} / \mathrm{min}$. The pressure upstream of the filter increased to $14 \mathrm{psi}$ before finally stabilizing at about $7 \mathrm{psi}$. After several filter volumes of feed through the filter, the color leaving the filter lightened so that hardly any was visible.

The volume of the $3 \mathrm{M}$ filter material used in this run was $1.29 \mathrm{~mL}$. This can be considered roughly equivalent to the column volume of an ion-exchange column for comparison of loading curves. Based on the average flow rate and filter volume, a flow rate in filter volumes per hour of 49.78 can be calculated for comparison with other sorbent materials.

The filter was operated through a complete loading/elution/regeneration cycle. When loading was complete, the supernatant feed to the column was stopped, and the feed lines were emptied. The filter feed pump was shut off to change to water rinse. About $15 \mathrm{~mL}$ of distilled water was passed through the filter. Then about $15 \mathrm{~mL} 0.5 \mathrm{MHNO}_{3}$ was added to the feed column to run through the filter for elution. After the acid had passed through the filter, a water rinse was passed through the filter. This was followed by pumping $2 M$ caustic through the filter material for regeneration. After the caustic started through the filter, significant colored effluent was again seen coming from the filter, and the pressure drop across the filter again caused pumping problems.

\subsubsection{Eichrome KCoFeC Granular Sorbent}

The granular sorbent used was a sample of $\mathrm{KCoFeC}$ material obtained from Eichrome, lot number JW-40-021. The material was prepared by filling a 10-mL graduate with $7.272 \mathrm{~g}(10-\mathrm{mL}$ tapped volume) of material and transferring this to the column to be used in the test. Next, $150 \mathrm{~mL}$ of distilled water was pumped through the column in upflow mode to remove fines and settle bed. A small amount of fines material (lightly covering the bottom of a $50-\mathrm{mL}$ beaker) was carried out of the column. After rinsing, the bed was settled and had a 6-cm depth $(10 \mathrm{~mL})$ before installation in the cell. The column was then installed, and supernatant feed was started. The supernatant feed was from the same bottle of W-27 supernatant that was used in the previous SuperLig ${ }^{\circledR}$ run at $6 \mathrm{CV} / \mathrm{h}$.

The test with $\mathrm{KCoFeC}$ was conducted at $9 \mathrm{CV} / \mathrm{h}$ using the supernatant at $\mathrm{pH} 12.85$, the same $\mathrm{pH}$ as in all previous tests on cesium removal materials. Immediately upon starting to feed supernatant to the column, a precipitate formed on the top of the bed. After a few minutes, the solids 
at the top of the bed had grown to what appeared to be a lump (about $1 \mathrm{~cm}$ thick) of cloudy material. No solids were present in the feed tank or in the lines to the column from the feed tank or pump.

After pumping supernatant through the column for about $12 \mathrm{~min}$, the downstream filter plugged and flow was switched to the alternate filter. Using the alternate filter decreased the pressure drop, but the filter gradually became covered to about $80 \%$ with a gray-brown precipitate. This was not enough to plug the filter and stop flow.

The cesium concentration in the column effluent was low during the start of the experiment and gradually increased as the first $100 \mathrm{CV}$ of supernatant passed through the column. After samples were collected in the fraction collector, the effluent samples were filtered using a $0.2-\mu \mathrm{m}$ filter. This procedure showed that, in fact, the increase is cesium was almost entirely due to particles of the $\mathrm{KCoFeC}$ leaving the column and passing through the $0.45-\mu \mathrm{m}$ filter and entering the rest of the system. The normal column operation continued for over $250 \mathrm{CV}$ in this manner. However, the material in the column then apparently began to disintegrate, because the cesium level in the effluent rose rapidly and could not be filtered out by using the $0.2-\mu \mathrm{m}$ filters. The ${ }^{137} \mathrm{Cs}$ level in the samples rose to greater than the concentration in the feed.

The column bed also lost volume during this time as the level in the bed fell from about 6.3 to $5.2 \mathrm{~cm}$ during about $6 \mathrm{~h}$ of continued operation. Following the feed shutdown to the column, it was rinsed with distilled water, drained, and removed from the system for counting. The system downstream from the column was coated with precipitate, which was difficult to remove. It was found that most of the precipitate was dissolved after treatment with caustic followed by acid.

\subsubsection{Conclusions}

To compare all the tested materials, the breakthrough curves were plotted on the same basis. The CST-38B material performed better overall than any of the other materials, based on CV to $50 \%$ breakthrough as compared at either 3 - or $6-\mathrm{CV} / \mathrm{h}$ flow rate using the $\mathrm{W}-27$ feed at $\mathrm{pH} 12.85$. The CST was also able to limit the cesium to less than $1 \%$ breakthrough for much longer than the other materials (except for the filtered effluent from the $\mathrm{KCoFeC}$ material). This means that the column effluent from the CST columns contained lower levels of cesium (e.g., a $\mathrm{C} / \mathrm{C}_{0}$ of 0.01 indicates $99 \%$ removal of the cesium) than with the SuperLig ${ }^{\circledR}$ or $3 \mathrm{M}$ WEB materials, which showed almost immediate breakthrough of more than 1 to $5 \%$ at less than $10 \mathrm{CV}$. The Eichrome $\mathrm{KCoFeC}$ showed good cesium removal for over $200 \mathrm{CV}$ as long as the samples were filtered through $0.2-\mu \mathrm{m}$ filters 
prior to analyzing for ${ }^{137} \mathrm{Cs}$; however, after $250 \mathrm{CV}$ the effluent contained more cesium than the feed because of the chemical breakdown of the sorbent.

\subsection{SLUDGE WASHING AND DISSOLUTION OF ORNL MVST WASTE: DATA FOR MODELING SLUDGE SCIENCE (E. C. Beahm, S. A. Bush, C. W. Chase, J. L. Collins, and T. A. Dillow)}

Contact: E. C. Beahm

Telephone: (423) 574-6851

Internet: beahmec@ornl.gov

Summary: Seven samples of Hanford underground storage tank sludge were obtained. Three caustic treatment tests were conducted on sludge from Hanford Underground Storage Tank $\mathrm{T}-104$ to assess the distribution of species between aqueous solutions and solids and to evaluate gel formation. Analytical results from these tests showed that comparable amounts of aluminum were removed at all three temperatures but that a greater removal of phosphate occurred in the room temperature test than in the tests at elevated temperature. Chromium removal was enhanced by leaching at elevated temperatures. Gels were observed in leachates from the tests at elevated temperatures $1 \mathrm{~d}$ after the treatments concluded, and a gel formed in the first wash after leaching in the room temperature test.

\subsubsection{Purpose and Scope}

A particular objective of selected washing and leaching tests is to minimize the resulting TRU residue that would be dissolved. A series of washing steps at decreasing $\mathrm{pH}(14,12,10$, and 8) may remove sludge components into supernatants. Equally important in these wash steps is to not dissolve the TRU components and to determine the transfer of fission products (selenium, technetium, iodine, cesium, etc.). After the TRU sludge has been minimized in these washing steps, a selective leaching series of experiments can determine the TRU dissolution from the sludge. It may be possible to dissolve the TRU components from the washed sludge, leaving a non-TRU residue.

\subsubsection{Progress}

Two aspects of caustic treatment of sludge should be well delineated and predictable: (1) the distribution of chemical species between aqueous solutions and solids and (2) potential problems that could result in process difficulties or safety concerns. The principal aim of caustic leaching is to remove aluminum, phosphate, chromium, and iron from sludge solids. In a successful treatment, these materials will enter leachates and wash solutions. However, aluminum, phosphate, and silica can form gels; therefore, an effective treatment for putting these materials in solution also provides material which may gel. The situation is exacerbated by washing, which has the effect of reducing 
the caustic concentration and, as a result, reducing the solubility of species that dissolved in the caustic. Gelation in leachates and wash solutions is unacceptable because it could (1) prevent mixing, (2) prevent pumping, (3) retard separations, (4) coat surfaces, and (5) clog filters.

Three caustic treatment tests were conducted on sludge from Hanford Underground Storage Tank T-104 to assess the distribution of species between aqueous solutions and solids and to evaluate gel formation. The tests were run at room temperature and at 60 and $95^{\circ} \mathrm{C}$. The samples were washed with "inhibited water" ( $0.01 M$ sodium hydroxide plus $0.01 M$ sodium nitrite), then leached twice with $3 M$ sodium hydroxide, and finally washed three times with inhibited water.

Analytical results from these tests showed that comparable amounts of aluminum were removed at all three temperatures. Most of the aluminum appeared in the first leachate solutions. There was a greater removal of phosphate in the room temperature test than in the tests at elevated temperature. Most of the phosphate removed in the room temperature test appeared in the first two washes after leaching, whereas phosphate removal in the tests at the elevated temperatures occurred during the two leaches. Chromium removal was enhanced by leaching at elevated temperatures. Gels were observed in leachates from the tests at elevated temperatures $1 \mathrm{~d}$ after the treatments concluded. The gel was a sodium fluoride phosphate. In addition, a gel formed in the first wash after leaching in the room temperature test. This wash solution had the highest phosphate concentration of any of the solutions in these tests.

Seven samples of Hanford underground storage tank sludge have been obtained. The samples were unpacked from the shipping containers and sorted according to radiation dose rate. Sludge from Tank B-202 had a dose rate low enough that it could be handled and tested in a laboratory hood. The other sludge samples were from Tanks S-104, T-107, C-107, BX-105, C-108, and TY-104. 


\title{
2. REACTOR FUEL CHEMISTRY
}

\author{
E. C. Beahm
} TECHNICAL ASSISTANCE IN REVIEW OF ADVANCED REACTORS (E. C. Beahm,
C. F. Weber, S. A. Bush, T. A. Dillow, and R. J. Weaver)

Contact: E. C. Beahm

Telephone: (423) 574-6851

Internet: beahmec@ornl.gov

Summary: The distribution of iodine in the containment vessel during an AP600 design basis accident (a medium loss-of-coolant accident) was evaluated using a group of models known collectively as the TRENDS code. Results of previous studies have shown that $\mathrm{pH}$ is the major factor in determining the amount of $\mathrm{I}_{2}$ and organic iodides in containment water pools. When the $\mathrm{pH}$ is $<7$ (acidic), these volatile iodine species can form. The AP600 3BE accident sequence calculations showed that $\mathrm{pH}>7$ was maintained for at least $30 \mathrm{~d}$. Because the $\mathrm{pH}$ was maintained above 7 , most of the iodine was in the form of iodide in water pools and not in a volatile form such as $\mathrm{I}_{2}$ or an organic iodide.

\subsection{PURPOSE AND SCOPE}

The objective of this project is to provide assistance to the U.S. Nuclear Regulatory Commision staff in reviewing the four advanced reactor designs submitted under 10 CFR Part 52. This work specifically addresses the following issues: (1) the distribution of iodine species in containment following a loss-of-collant accident, (2) the generation of hydrochloric acid and nitric acid by irradiation and heating in containment, (3) the formation of elemental iodine in containment water that has both chloride and iodide ions, and (4) the evaluation of $\mathrm{pH}$ levels in containment water.

\subsection{PROGRESS}

Results of previous studies have shown that $\mathrm{pH}$ is the major factor in determining the amount of $\mathrm{I}_{2}$ and organic iodides in containment water pools. When the $\mathrm{pH}$ is $<7$ (acidic), these volatile iodine species can form. The major contributors to acidity are the acids (hydrochloric and sulfuric) produced by the irradiation and/or heating of Hypalon ${ }^{\mathrm{TM}}$ (a registered trademark of DuPont for chlorosulfonated polyethylene rubber) cable jacketing material. Pyrolysis of Hypalon TM jacketing material from a high-voltage cable produced up to $2.7 \mathrm{~mol} / \mathrm{kg}$ of hydrochloric acid and up to $0.1 \mathrm{~mol} / \mathrm{kg}$ of sulfuric acid. When this is scaled to the amount of jacketing material proposed for an AP600 containment, the maximum acid production becomes $3.6 \times 10^{4} \mathrm{~mol}$ hydrochloric acid and $1.5 \times 10^{3} \mathrm{~mol}$ sulfuric acid. In spite of these amounts of acid, tests with the appropriate mixtures of acids and bases showed that the AP600 $\mathrm{pH}$ control chemicals could maintain $\mathrm{pH}>7$. 
The distribution of iodine in containment during an AP600 design basis accident was evaluated using a group of models known collectively as the TRENDS code. In this study, the 3BE sequence, a medium loss-of-coolant accident, was examined. In this analysis, thermal hydraulic data were inserted into TRENDS models along with physical and chemical parameters specific to AP600 containment. The calculations were performed for periods of time up to $24 \mathrm{~h}$ into the accident sequence based on thermal hydraulic data from the MAAP code. This data was extrapolated to permit an evaluation of iodine behavior for a 30-d period.

The AP600 3BE accident sequence calculations showed that $\mathrm{pH}>7$ was maintained for at least 30 d. More than $5000 \mathrm{~mol}$ of hydrochloric acid from Hypalon ${ }^{\mathrm{TM}}$ jacketing was indicated in the calculations. Because the $\mathrm{pH}$ was maintained above 7, most of the iodine was in the form of iodide in water pools and not in a volatile form such as $\mathrm{I}_{2}$ or an organic iodide. The overall iodine distribution was aqueous iodide $(66.7 \%)$, iodide deposited on surfaces $(33.7 \%)$, aqueous $\mathrm{I}_{2}$ $\left(2 \times 10^{-5} \%\right)$, and $\mathrm{I}_{2}$ in vapor phase $\left(2 \times 10^{-6} \%\right)$.

\section{THERMODYNAMICS}

\section{T: B. Lindemer}

\section{THERMODYNAMICS AND KINETICS OF ENERGY-RELATED MATERIALS (T. B. Lindemer)}

Contact: T. B. Lindemer

Telephone: (423) 574-6850

Internet: lindemertb@ornl.gov

Summary: Several different experiments are in progress to obtain information on the effects of oxygen nonstoichiometry, temperature $(T)$, and oxygen partial pressure $(p)$ on the superconducting transition temperature $\left(\mathrm{T}_{c}\right)$ and phase behavior of $\mathrm{R}-\mathrm{Ba}-\mathrm{Ca}-\mathrm{Cu}-\mathrm{O}$ compounds. Experimental work continues on the T-p-z-y interdependence in the $\mathrm{Pd}_{1+z} \mathrm{Ba}_{2-z} \mathrm{Cu}_{3} \mathrm{O}_{\mathrm{y}}$ solid solution. The effect of specimen density, temperature, and grain size on the attainment of equilibrium $7-\mathrm{x}$ values is also being investigated for the $\mathrm{YBa}_{2} \mathrm{Cu}_{3} \mathrm{O}_{7-\mathrm{x}}$ (Y123) system. To date, thermogravimetric analysis (TGA) experiments have been done with the world's largest Y123 single crystal, a 95-g specimen, and a similar 15-g crystal, both of which are theoretically dense. The TGA experiments have defined the initial 7- $\mathrm{x}$ value. Two journal articles have been published.

\subsection{PURPOSE AND SCOPE}

The objective of this program is measurement and interpretation of chemical thermodynamics in applied-technology ceramic systems. Presently, this project concerns phase equilibria and 
thermodynamics of the $\mathrm{R}-\mathrm{Ba}-\mathrm{Ca}-\mathrm{Cu}-\mathrm{O}$ system, with $\mathrm{R}$ representing $\mathrm{Y}, \mathrm{La}, \mathrm{Pr}$ and $\mathrm{Nd}$. Emphasis is being placed on the phase fields that include the superconducting compounds.

\subsection{PROGRESS}

Several different experiments are in progress to obtain information on the effects of oxygen nonstoichiometry, temperature $(T)$, and oxygen partial pressure (p) on the superconducting transition temperature $\left(\mathrm{T}_{\mathrm{c}}\right)$ and phase behavior of $\mathrm{R}-\mathrm{Ba}-\mathrm{Ca}-\mathrm{Cu}-\mathrm{O}$ compounds. The primary experimental techniques used are X-ray diffraction, differential thermal analysis, thermogravimetric analysis (TGA), and measurement of $T_{c}$. The results during the past quarter are as follows.

Two journal articles have been published. The first, a paper concerning the $\mathrm{Ba}-\mathrm{Cu}-\mathrm{O}$ system, which is one of the important subsets of the superconducting oxide systems, has been published by Physica C [T. B. Lindemer and E. D. Specht, "The Ba-Cu-CuO System: Solid-Liquid Equilibria and Thermodynamics of $\mathrm{BaCuO}_{2}$ and $\mathrm{BaCu}_{2} \mathrm{O}_{2}$," Physica C, 255 (1\&2), 81-94 (1995)]. A second paper concerning experimental work in the $\mathrm{Nd}_{1+z} \mathrm{Ba}_{2-z} \mathrm{Cu} \rho_{y}$ solid solution, which is one of the oxide superconductors, has also been published by Physica C [T. B. Lindemer, E. D. Specht, P. M. Martin, and M. L. Flitcroft, "Non-stoichiometry, Decomposition and $\mathrm{T}_{\mathrm{c}}$ of $\mathrm{N}_{1+z} \mathrm{Ba}_{2-\mathrm{z}} \mathrm{Cu}_{3} \mathrm{O}_{\mathrm{y}}$ ”" Physica C, 255 (1\&2), 65-75 (1995)].

Experimental work continues on the T-p-z-y interdependence in the $\mathrm{Pd}_{1+z} \mathrm{Ba}_{2-z} \mathrm{Cu}_{3} \mathrm{O}_{\mathrm{y}}$ solid solution. At $z=0$, there was a T-p dependence for the existence of either single-phase or multiphase regions; since a single phase must be present at all times, y could not be determined. Measurements at $\mathrm{z}=0.125,0.25$, and 0.4 have been completed on single-phase material and the data is well behaved; work at $\mathrm{z}=0.6$ remains to be done.

Cooperative work on the $\mathrm{YBa}_{2} \mathrm{Cu}_{3} \mathrm{O}_{7-\mathrm{x}}(\mathrm{Y} 123)$ system has been initiated with Mona Yethiraj, Bryan Chakoumakos, and Herb Mook of the Solid State Division at ORNL. In spite of the fact that this superconducting oxide has been extensively studied for many years, there are apparently only two reasonably definitive studies of the relationship between $7-x$ and the lattice parameter. Such information is needed for the fundamental analysis of the solid-state physics of the compound. However, the earlier results are inconsistent with other solid-state measurements. Thus, seventeen $12-\mathrm{g}$ specimens were prepared to give known $7-\mathrm{x}$ values. These specimens were used by the coinvestigators in neutron diffraction experiments that gave a very orderly dependence of the three lattice parameters on $7-x$ and that are considerably different from the previous work. The superconducting transition temperature was also measured on all the specimens, and reasonably good 
agreement was found with the earlier work. Finally, hydrogen reductions of the specimens were performed to confirm the $7-\mathrm{x}$ values. This data set is now being analyzed further.

The effect of specimen density, temperature, and grain size on the attainment of equilibrium $7-x$ values is also being investigated. To date, TGA experiments have been done with the world's largest Y123 single crystal, a 95-g specimen, and a similar 15-g crystal, both of which are theoretically dense. The TGA experiments have defined the initial 7-x value, which has been of great help to the solid-state physicists, and the T-p-t conditions for practical attainment of equilibrium $7-\mathrm{x}$ values in a massive crystal. Part of this crystal was then ground to a powder, and this subdivision permitted equilibrium to be attained at much lower temperatures. A $15-\mathrm{g}$, meltprocessed, lower-density polycrystalline sample was also treated and apparently behaved in a manner lying between that for the single crystal and its powder; this sample has also been used to determine chemical diffusion coefficients of oxygen from 400 to $900^{\circ} \mathrm{C}$.

\section{PROCESSES FOR WASTE MANAGEMENT}

\section{J. C. Rudolph}

\section{ION EXCHANGE PROCESS FOR HEAVY METALS REMOVAL (J. C. Rudolph, K. E. Murphy, and M. R. Gibson)}

Contact: J. C. Rudolph

Phone: (423) 574-6882

Internet: rudolphjc@ornl.gov

Summary: This project is the demonstration of a pilot-scale ion-exchange system to remove heavy metals from multiple sites (originally from an acid mine site only) using the most effective commercially available sorbent based on laboratory screening experiments. This system will operate alongside three novel treatment systems and act as baseline technology. In the past quarter, a column test using Amberlite IRC- $50^{\mathrm{TM}}$ was performed based on the composition of the original acid mine site with $2 \mathrm{ppm}$ of zinc added. This column ran 5000 bed volumes (BV) before breakthrough of zinc. Unfortunately, this site is no longer going to be used in the program, and no information on the new sites has yet been received. The conceptual design of the pilot-scale system has been completed, and purchase of the necessary equipment is under way.

\footnotetext{
"CKY, Incorporated, Oak Ridge, Tennessee.
} 


\subsection{PURPOSE AND SCOPE}

The scope of this project has been modified. The original scope was to demonstrate the ability of a pilot-scale ion-exchange system to remove heavy metals from an acid mine drainage site. An initial screening of materials was to be performed to choose the most effective sorbent. This process would then serve as a baseline to compare the abilities of three new innovative technologies to treat the same stream. The modified scope is now looking at heavy metals contamination at multiple sites, none of which are mine drainage sites. This expands the scope since each stream must be treated separately for purpose of screening tests.

\subsection{PROGRESS}

A column test using Amberlite IRC- $50^{\mathrm{TM}}$ was performed using a simulant. The simulant was based on the analysis of the gravity slope discharge with a $2.3 \mathrm{ppm}$ spike of $\mathrm{ZnCl}_{2}$ added. IRC-50 was chosen based on batch equilibrium and kinetic tests performed in July and August. The effluent zinc concentration was below detection levels for the first $5000 \mathrm{BV}, \sim 1500 \mathrm{~L}$. After $7000 \mathrm{BV}$ the effluent concentration was at $30 \%$ of the inlet concentration. The flow rate through the column was $2.3 \mathrm{gpm} / \mathrm{ft}^{2}$. This is a flux rate comparable with that used in industrial-scale columns; however, the performance in a deeper column is likely to be improved because of the greater bed contact times exhibited in those systems. The overall capacity exhibited by the resin was 2 equiv/ $\mathrm{L}$ of resin in sodium form, which is in agreement with values recorded in the literature.

The program was placed on hold for 1 month, and the scope of the program was altered by program management. The program is now examining the possibility of moving the four technologies to several sites that have heavy metals contamination problems. The sites are no longer mine drainage sites but are private waste streams. At present, we are unsure as to the composition of these streams, which delays further testing on ion-exchange materials; however, design of the system is progressing.

The conceptual design of the pilot-scale system has been completed. Purchase of equipment is under way, and construction will begin in January 1996. A trailer is being obtained in-house for use on this project. 


\title{
5. U.S. ARMY FIELD ARTILLERY LIQUID PROPELLANT STABILITY PROGRAM: WORK FOR OTHERS
}

Contact: A. J. Mattus

\author{
A. J. Mattus
}

Phone: (423) 576-1795

Internet: mattusaj@ornl.gov

Summary: Pressure-rise scoping tests for the U.S. Army continued at both 50 and $65^{\circ} \mathrm{C}$. Some tests in which a special inorganic stabilizer was used to stabilize the energetic liquid propellant (LP) have now exceeded $120 \mathrm{~d}$ without any increase in pressure associated with the decomposion of the LP into various gaseous degradation by-products. The additive appears to be the answer to the Army's long search for an acceptable stabilizer. In the coming weeks, the Army will test the additive in the Army Research Laboratory (ARL) at the Aberdeen Proving Ground to investigate its stability at higher controlled temperatures as well as to investigate its effect upon the burn rate of the LP in calorimeters.

\subsection{PURPOSE AND SCOPE}

The primary objective of this work-for-others program is to supply the ARL at Aberdeen, Maryland, with potential means for increasing the storage and handling stability of their LPXM-46 liquid propellant. This two-year program is being coordinated through the Robotics and Process Systems Division and has a multidivisional team with the following tasks: (1) determine chemical analysis needs, (2) evaluate stabilizing techniques used with relevant analog compounds, (3) evaluate prior work related to propellant stability and decomposition, (4) assess material compatibility, and (5) develop and execute a crosscutting experimental program. Task 2 is the primary task for this team member and will be limited to a paper study and experimental work to test various stabilizers.

\subsection{PROGRESS}

During this quarter, pressure-rise scoping tests for the U.S. Army continued at both 50 and $65^{\circ} \mathrm{C}$. Some tests in which a special inorganic additive was used to stabilize the energetic liquid propellant (LP) have now exceeded $120 \mathrm{~d}$ without any increase in pressure associated with the decomposion of the LP into various gaseous degradation by-products. The pressure change curves for the control sample in quartz tubes without any stabilizers are indistinguishable from those of the tests containing $25 \mathrm{ppm}$ iron and the inorganic additive. For comparison, after $41 \mathrm{~d}$, the LP containing iron and no stabilizer vented pressure through its safety valve. The additive appears to be the answer to the Army's long search for an acceptable stabilizer.

The additive has a negative charge that is well suited for removing metal cations from solution, as well as protons, which can be produced as another degradation by-product in the LP. This acid, 
in the form of nitric acid, also promotes an increase in the rate of LP decomposition. The additive acts to inhibit any increase in the activity of hydrogen cations. The additive functions take up protons and become positively charged.

Since the properties of the LP mimic that of a molten salt and consequently since it is very lean in water, it is believed that there may be a driving force which favors the movement of iron with its incomplete hydration sphere towards the additive. Since many of the cations and anions in the LP are void of water molecules in their hydration shells, they are forced to face each other. Consequently, metal cations surrounded by any water molecules may exhibit a haliophobic-like effect and be driven to the high specific surface of the additive which holds on to water very well. This effect may be similar to that observed with a nonpolar organic molecule that is attracted to charcoal in aqueous solution, a phenomenon partially due to electrostatic effects but also due to hydrophobic driving forces.

In the coming weeks, the Army will test the additive in the ARL at the Aberdeen Proving Ground to investigate its stability at higher controlled temperatures as well as investigate its effect upon the burn rate of the LP in calorimeters. Since the additive acts much as an inert phase and does not affect the chemistry of the LP, it is expected to perform well. 
ORNL/M-5018

\section{INTERNAL DISTRIBUTION}

1. J. M .Begovich

2. C. H. Byers

3. E. D. Collins

4. A. G. Croff

5. L. D. Duncan

6-31. B. J. Johnson

32. T. R. Jones

33. R. T. Jubin

34. L. E. McNeese

35. G. E. Michaels

36. B. D. Patton

37. D. E. Reichle

38. S. M. Robinson

39. T. W. Schmidt

40. G. W. Strandberg

41-42. ORNL Laboratory Records

43. ORNL Laboratory Records-RC

44. ORNL Patent Office

45. Central Research Library

46. Y-12 Technical Library,

Document Reference Center

\section{EXTERNAL DISTRIBUTION}

47-48. Office of Scientific and Technical Information, P.O. Box 62, Oak Ridge, TN 37831 